\title{
IMPACTS OF GOOGLE FORMS ON ENGLISH - MAJORED STUDENTS' LISTENING SKILL
}

Vu Thi Quyen*, Bui Ngoc Anh

$T N U$ - School of Foreign Languages

\begin{tabular}{|c|c|c|}
\hline \multicolumn{2}{|c|}{ ARTICLE INFO } & \multirow{3}{*}{$\begin{array}{l}\text { ABSTRACT } \\
\text { The study aims at investigating the influence of Google Forms on } \\
\text { English majored students' listening skill at the School of Foreign }\end{array}$} \\
\hline Received: & $16 / 3 / 2021$ & \\
\hline Revised: & $30 / 3 / 2021$ & \\
\hline & & Languages, Thai Nguyen University. There was a controlled group in \\
\hline Published: & $31 / 3 / 2021$ & $\begin{array}{l}\text { which the students were given printed homework and an experimental } \\
\text { group in which the participants were sent listening homework designed }\end{array}$ \\
\hline \multicolumn{2}{|l|}{ KEYWORDS } & on Google Forms. Hence, the students in the controlled group could not \\
\hline \multicolumn{2}{|l|}{ Google Classroom } & experimental group could check their answers and tapescript after their \\
\hline \multicolumn{2}{|l|}{ Google Forms } & submission. The research employed tests and a questionnaire for the \\
\hline \multicolumn{2}{|l|}{ Listening skill } & data collection. The study shows that the students in the experimental \\
\hline \multicolumn{2}{|c|}{ Listening assignment } & $\begin{array}{l}\text { group got more success in listening tests than the students in the } \\
\text { controlled group. Additionally, the students found doing homework on }\end{array}$ \\
\hline \multicolumn{2}{|c|}{ Homework management } & $\begin{array}{l}\text { Google Forms motivating. Hence, they looked forward to listening } \\
\text { assignments in other listening courses. The study can bring teachers } \\
\text { who are in charge of listening lessons some ideas for listening } \\
\text { homework management. }\end{array}$ \\
\hline
\end{tabular}

\section{ẢNH HƯởNG CỦA GOOGLE FORMS ĐÔI VỚI KỸ NĂNG NGHE CỦA SINH VIÊN CHUYÊN NGÀNH TIẾNG ANH}

\author{
Vũ Thị Quyên", Bùi Ngọc Anh
}

Trưòng Ngoại ngũu - ĐH Thái Nguyên

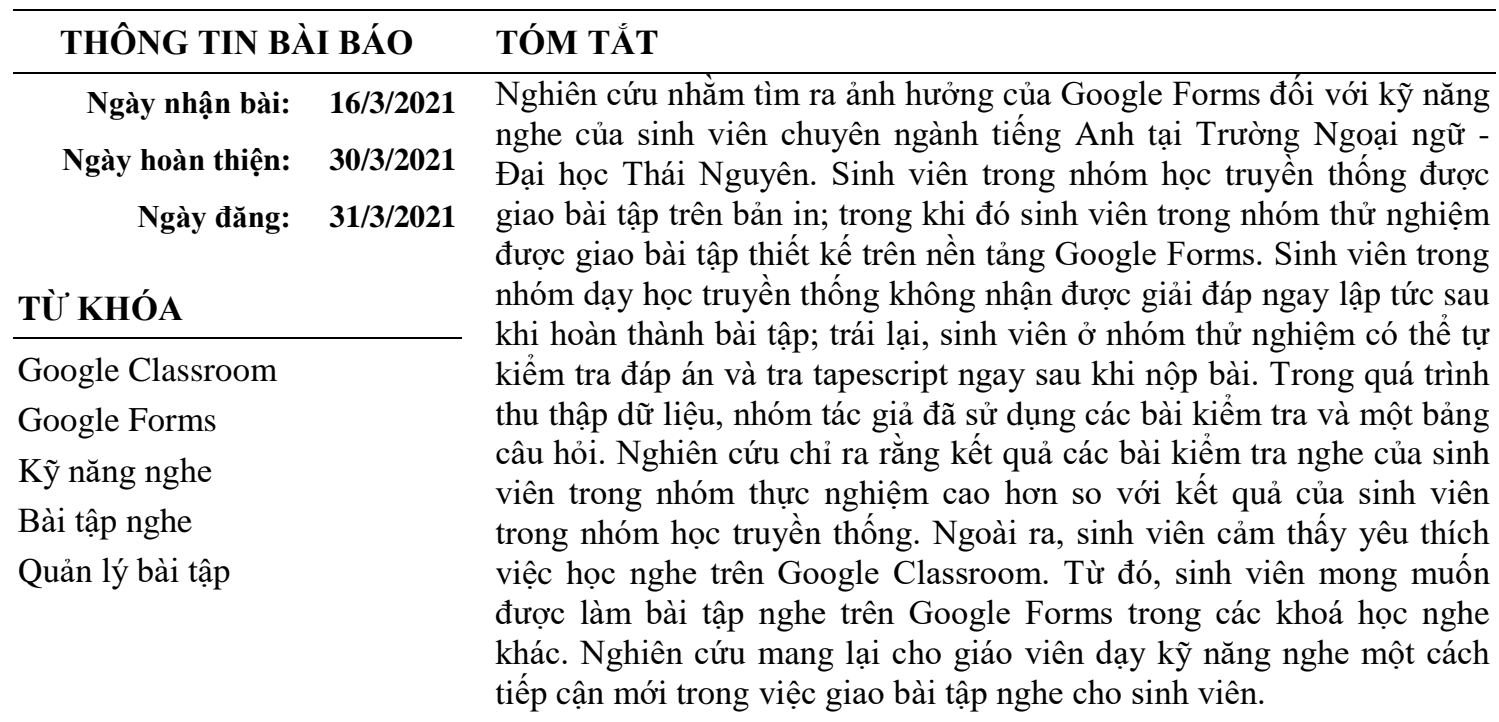

DOI: https://doi.org/10.34238/tnu-jst.4176

* Corresponding author. Email: vuquyen.sfl@tnu.edu.vn 


\section{Introduction}

Many human beings' activities have been remarkably changed since the beginning of the $21^{\text {st }}$ century and after the industry 4.0 era was declared. Hamiti \& Blerim Reka [1] indicate that education, industry, social philosophy, psychology, culture, political philosophy, and human behaviors follow this disruption era. In education particularly, teachers and educators are facing up with the challenges brought by the changes. They are finding ways to improve students' autonomy as well as the efficiency of the teaching and learning process. On the case, technology, which is believed to be able to enrich the learning environment by transferring teaching instruments toward student-centered, has been commonly used in education [2]. Teachers are quite familiar with computers, softwares, platforms, online materials and some kinds of modern teaching approaches namely distance learning, flipped learning and blended learning, which can support the teaching - learning process.

In School of Foreign Languages, Thai Nguyen University, blended learning has been implemented frequently by most teachers. Blended leaning is defined as the combination of different instructional methods; the combination of different modalities or delivery media; the combination of face-to-face instruction with computer-mediated instruction [3], [4]. In the school, blended learning means the combination between face-to-face instructions and computermediated instructions. The teachers deliver their lectures in classrooms; and then they send the students weekly assignments on Google Classroom as their homework.

Due to the break-out of COVID 19 in Vietnam at the beginning of 2020, students at the school had new experience of distance learning in which they joined online lessons with their teachers on zoom.com or googlemeet.com. Additionally, they were sent lots of homework assignments on Google Classroom. Google Classroom was selected as a channel to send students homework because it is far better in the areas of communication, interaction, perceived usefulness, ease of use, and overall students' satisfaction [5]. Moreover, Google Classroom plays a great role in making learning more easily as it is extremely useful in understandability, attractiveness, and operability [6]. The researchers were in charge of listening lessons for English majored students. Hence, the researchers had to find ways to apply the free platform in effectively controlling students' listening homework. After some insight searches, Google Forms, which are available in Google Classroom, were selected by teachers of listening skill.

Google Forms provide teachers a number of benefits for training courses since the application is free. Besides, Chaiyo \& Nokham [7] state that Google forms help to facilitate online survey, questionnaire, and quiz design with a user-friendly interface process. Their list includes six advantages of Google Forms: (1) It is easy to add questions, choose question types, size comparisons, and brief instructions or test analysis notes. (2) Survey results are automatically saved in Google sheets centralized in Google Drive. (3) There is no limitation of the total number in using survey forms or the number of students who can participate in this survey. (4) Google Forms can provide the administrators with information through emails whenever a response is sent. (5) Google Forms give users choices about the types of questions to be made, for example multiple-choice questions, essays, or short answers. (6) Google Forms can save pre-filled forms and insert images, and add surveys on web pages. Thanks to the advantages of Google Forms, the researchers find the application beneficial to listening homework designing and managing.

Regarding listening in classroom, listening is defined by many scholars. Listening comprehension means that a person can understand everything that he/she has heard [8], [9]. Additionally, listening comprehension is; theoretically, an active process where individuals must concentrate on specific aspects of aural input, form the meaning of parts of the text, and listeners must be able to relate what they hear to existing knowledge [10], [11]. To sum up, listening comprehension is the process of one individual perceiving another via sense, (specifically aural) organs, assigning a meaning to the message and comprehending it [12]. In School of Foreign 
Languages, students have listening exercises in the course book and are sent extra listening exercises on Google Classroom; however, there were no tapescript and answer keys attached. This way of giving assignments can save time to teachers, but students can not access feedback toward their listening performance. This study aims at answering the two questions: (1) What benefits do students get from listening assigments on Google Forms? And (2) What is students' attitude toward listening homework designed on Google Forms?

\section{Methodology}

This study focuses on the influence of listening homework designed on Google Forms toward students' listening skill. The population of the research were 180 second-year English - majored students at School of Foreign Languages, Thai Nguyen University. Among them, there were 11 males and 169 females. The students were divided randomly into 6 classes by the School's Training Department.

Regarding the listening materials for $2^{\text {nd }}$ year students; because the target level of the students was B1, the series of Books entitled Primary English Test for School by Cambridge University was applied in the study as the extra materials. Moreover, the books were suggested in the course outline of the subject. Each listening assignment includes four parts: In Part 1, there were seven question items, each of which contains a question and three pictures; students listened to a short conversation and choose the picture to answer each question. In Part 2, students listened to a three or four minute conversation and answer six multiple choice questions. In Part 3, students listened to a short presentation or a short speech and filled in six blanks in a summary of the talk. In Part 4, students listened to a conversation and decided six statements True or False. In the course, there were 15 lessons, which were arranged in 15 weeks. In other words, there were 15 listening documents sent to the students.

In the study, the participants were divided into two groups. 90 of them were in the controlled group in which they were sent listening homework on Google Classroom. The researchers sent them with audio files and PDF or doc files which concluded question items. The students were asked to print the materials, to do the homework and to bring them to the classroom. The teachers might show them the keys and share why they got incorrect answers by playing the audio and explain the keys if they had time. If there was a limitation of the time, the teachers read the keys only. The rest of students were classified in the experimental group in which they were sent the listening homework on Google Forms, which were created in folders in Google Classroom. The forms allowed the students to check their answers after their submission. Moreover, the tapescripts of the audios, which were cut as pictures, also were inserted in the forms after each listening section. Obviously, students' names, answers, time and dates were shown clearly so that lectures could manage them with no challenges. Additionally, among the 90 students, there were 10 students who did not have a desktop, a laptop or a smart phone. Hence, the researchers asked them to visit the Learning Resources and Information Technology Center, Thai Nguyen University for the free desktop and internet connection.

To collect data for the study, tests and a questionnaire were applied. The students were asked to take five tests: a diagnostic test in the first week to find out the students' levels and the differences in the students' levels between the controlled group and the experimental one. Moreover, two mini tests in the $3^{\text {rd }}$ and $10^{\text {th }}$ week as well as two progress tests in the $7^{\text {th }}$ and $14^{\text {th }}$ week were taken by the participants. The test questions were taken from Books of Primary English Test for School by Cambridge University so that all the test qualities including reliability, validity, practicality and authenticity were met. All the students' results were carefully kept and analyzed. There were 25 questions in each test and the participants got 0.4 point for a correct answer. In other words, participants got 10 points if they got all 25 correct answers.

At the end of the course, a questionaire was delivered to the 90 participants in the experimental group in order to investigate their feedback on the listening homework which was 
designed on Google Forms. The questionaire was adapted from Adit Gupta and Pooja Pathania [13]. There were two parts in the questionnaire: The first part included some questions to get personal information from the participants. The second part had eight questions which helped the researchers collect participants' attitude toward the ease of listening homework designed on Google Forms.

\section{Findings and discussion}

As being mentioned in the previous part, the controlled group were sent printed documents while the experimental group were sent listening homework on Google Forms. After the study, there was a change in the test results gained by the two groups. The results of the five tests will be shown in the table 1 .

Table 1. Participants' average scores

\begin{tabular}{lcc}
\hline & $\begin{array}{c}\text { Average scores } \\
\text { Controlled group }\end{array}$ & $\begin{array}{c}\text { Average scores } \\
\text { Experimental group }\end{array}$ \\
\hline Diagnostic test $\left(1^{\text {st }}\right.$ week $)$ & 5.61 & 5.54 \\
Mini test $1\left(3^{\text {rd }}\right.$ week $)$ & 5.71 & 5.75 \\
Progress test $1\left(7^{\text {th }}\right.$ week $)$ & 6.02 & 6.34 \\
Mini test 2 $\left(10^{\text {th }}\right.$ week $)$ & 6.12 & 6.57 \\
Progress test $2\left(14^{\text {th }}\right.$ week $)$ & 6.23 & 6.65 \\
\hline
\end{tabular}

From the table 1 , it is easy to find out two main points. Firstly, there was no significant difference in the listening results before the experiment. In the diagnostic test, the average score of the controlled group was 5.61 while the average score gained by the students in the experimental group was 5.54. The gap was only 0.09 point. Secondly, results for listening tests of the participants in the two groups were gradually improved after the tests. The average scores gained by the students in the controlled group were increased by 0.62 from 5.61 for the diagnostic test to 6.23 for the progress test 2 . In contrast, the students in the experimental group got more achievement than their fellows in the controlled group because their average scores in the progress test 2 were 1.11 point higher than their results in the very first test. Additionally, their average score at the progress test 2 was 0.42 higher than the average scores got by the students in the controlled group.

The change can be explained that thanks to the keys that was provided after each part of the test on Google Forms, the students could check their answers right after they submitted the test. It was the keys that helped the students more motivated in learning. Moreover, thanks to the tapescript after each part of the assignments, the students could check why they did not get the correct answer so that they could draw some valuable lessons for other listening exercises in this revision step. Meanwhile, the students in the controlled group only sent the keys due to the time limitation. Therefore, many students might not know why they got wrong answers, or even when they got correct answers, they were not so sure why they got points in the questions because they failed accessing the tapescript. As a result, even though they finished all of the homework, they got no strategies to improve their ability of listening comprehension. It means that students could not get the benefits of feedback for their listening homework.

In order to investigate how much students appreciate the impacts of homework on Google Forms toward their listening skill, a questionnaire was sent to them on Google Forms. The result will be shown in the table 2 .

Table 2 shows $88.9 \%$ of the participants agreed that they could learn faster, more easily followed the assignments and more frequently remembered to do the homework on Google Forms. It is explained that the students could access to the homework whenever they connected with the Internet; they did not need to carry thick and heavy printed materials; they did not worry about loosing their printed homework because the Google Forms did it for them. Moreover, 
thanks to the Google Classroom, all the links for the homework were arranged in separate folders, it took them less time to find the assignments on Google Classroom than in the portfolio of the printed materials. Furthermore, Google Classroom usually reminded them before the deadline; hence, the students had no difficulty in remembering their homework.

Table 2. Participants' evaluation about impacts of listening homework on Google Forms toward their listening skill

\begin{tabular}{lcccccc}
\hline \multicolumn{1}{c}{ Item } & Agree & $\mathbf{\%}$ & Disagree & $\mathbf{\%}$ & Doubtful & \% \\
\hline $\begin{array}{l}\text { 1. I was able to learn faster through the } \\
\text { homework on Google Forms. }\end{array}$ & 80 & $\mathbf{8 8 . 9}$ & 10 & $\mathbf{1 1 . 1}$ & 0 & $\mathbf{0}$ \\
\hline $\begin{array}{l}\text { 2. I could follow the assignments on Google } \\
\text { Forms easily than the printed document. }\end{array}$ & 80 & $\mathbf{8 8 . 9}$ & 10 & $\mathbf{1 1 . 1}$ & 0 & $\mathbf{0}$ \\
\hline $\begin{array}{l}\text { 3. I forgot the homework less frequently than I } \\
\text { did with the printed homework. }\end{array}$ & 80 & $\mathbf{8 8 . 9}$ & 10 & $\mathbf{1 1 . 1}$ & 0 & $\mathbf{0}$ \\
\hline $\begin{array}{l}\text { 4. I felt relaxed when I did my homework on } \\
\text { Google Forms from my mobile devices. }\end{array}$ & 83 & $\mathbf{9 2 . 2}$ & 5 & $\mathbf{5 . 6}$ & 2 & $\mathbf{2 . 2}$ \\
\hline $\begin{array}{l}\text { 5. I could save more money with the homework } \\
\text { on Google Forms than the printed materials. }\end{array}$ & 80 & $\mathbf{8 8 . 9}$ & 5 & $\mathbf{5 . 6}$ & 5 & $\mathbf{5 . 6}$ \\
\hline $\begin{array}{l}\text { 6. I was able to check my answers easily } \\
\text { through Google Forms. }\end{array}$ & 90 & $\mathbf{1 0 0}$ & 0 & $\mathbf{0}$ & 0 & $\mathbf{0}$ \\
\hline $\begin{array}{l}\text { 7. I could quickly get explanation for the } \\
\text { answers. }\end{array}$ & 90 & $\mathbf{1 0 0}$ & 0 & $\mathbf{0}$ & 0 & $\mathbf{0}$ \\
\hline $\begin{array}{l}\text { 8. I look forward to listening assignments on } \\
\text { Google Forms next terms. }\end{array}$ & 90 & $\mathbf{1 0 0}$ & 0 & 0 & 0 & $\mathbf{0}$ \\
\hline
\end{tabular}

Regarding the financial aspect, the same number of the participants responded that they could save money for the homework, because they did not have to spend money on printing the materials every week. However, there were about $11.1 \%$ of the students did not get the same experience that the homework on Google Forms brought to their fellows. When the researchers looked back their background, they noticed that all of these students announced that they did not have any media devices for the online assignments.

When students were asked about the ease to access Google Forms for their assignments, $100 \%$ of the participants admitted that they could check their results as well as the tapescript quicker than with the printed materials. Additionally, all of them showed that they appreciated the listening homework on Google Forms and they were eager for listening homework designed on Google Forms in other listening courses at the School.

\section{Conclusion}

To sum up, the listening homework on Google Forms could help the students gain more success in the listening tests than the printed homework. Besides, the assignments on Google Forms brought students with a lot of benefits, for example the ease to access the homework, which was proved by Adit Gupta and Pooja Pathania; and David [13], [14]. The finding of the study also shows that the access to keys as well as explanation was quicker on Google Forms than from the teachers. It was this benefit that helped students more motivated and their learning was more enjoyable. Finally, they got more success in listening skill and listening tests.

Although the researchers got students' results in the tests in the course for the data collections, they could not access the students' results in the ending course test from the School's training department because of the privacy policies. Hence, the researchers could not make the complete comparison in the differences in the two groups' results. Future researchers can take some consideration on the issues for a better study if they share the same interests with the current researchers. 
With regard to some other considerations which should be taken by teachers who take responsibility for listening skill, it takes much more time to design questions on Google Forms than printed questions. Each assignment takes the researchers twenty times longer to design an assignment on Google Forms than in PDF files. However, it is worth designing the assignments because they can be reduplicated for many courses and the homework can motivate students. Additionally, students who do not have any media devices may find this approach inconvenient as well as they may oppose the homework on Google Forms. Therefore, teachers are advised to persuade them to take advantages of their schools' computer rooms or their schools' libraries as they are living in the technology era and blended learning is inescapable.

\section{REFERENCES}

[1] M. Hamiti and B. Reka, "Teaching with Technology," Procedia - Social and Behavioral Sciences, vol. 46, December 2012, pp. 1171 - 1176. [Online]. Available: https://doi.org/10.1016/j.sbspro. 2012.05.269. [Accessed January 10, 2021].

[2] E. Wahyuni, "Teaching English with an Internet-Based Nature of Google Docs To Improve Students' Critical Thinking," International Journal of Education, vol. 10, pp.157, February 2018. [Online]. Available: https://doi.org/10.17509/ije.v10i2.7895. [Accessed January 10, 2021].

[3] C. R. Graham, S. Allen, and D. Ure, "Benefits and challenges of blended learning environments," Encyclopedia of Information Science and Technology, First Edition. IGI Global, 2005, pp. 253-259. [Online]. Available: https://doi.org/10.4018/978-1-59140-553-5. [Accessed February 15, 2021].

[4] M. Driscoll, "Blended learning: Let's get beyond the hype," E-Learning, vol. 1, no. 4, pp. 1-3, 2002. [Online]. Available: http://www-07.ibm.com/services/pdf/blended_learning.pdf. [Accessed February 10, 2021].

[5] T. Mayes, and S. de Freitas, "Learning and e-learning: the role of theory," in Rethinking pedagogy in the digital age, H. Beetham, and R. Sharpe, Eds. Routledge Publisher, 2007, pp. 13-25.

[6] K. K. Esteves, "Exploring Facebook to Enhance Learning and Student Engagement: A Case from the University of Philippines (UP) Open University," Malaysian Journal of Distance Education, vol. 14, no.1, pp. 1-5, 2012. [Online]. Available: http://mjde.usm.my/vol14_1_2012/mjde14_1_1.pdf. [Accessed February 12, 2021].

[7] Y. Chaiyo and R. Nokham, "The effect of Kahoot, Quizizz and Google Forms on the student's perception in the classrooms response system," 2nd Joint International Conference on Digital Arts, Media and Technology 2017: Digital Economy for Sustainable Growth (ICDAMT), January 2017, pp. 178-182. [Online]. Available: https://doi.org/10.1109/ICDAMT.2017.7904957. [Accessed February 12, 2021].

[8] A. P. Gilakjani and N. B. Sabouri, "Learners' Listening Comprehension Difficulties in English Language Learning: A Literature Review," English Language Teaching, vol. 9, no. 6, pp. 123, May 2016. [Online]. Available: https://doi.org/10.5539/elt.v9n6p123. [Accessed February 15, 2021].

[9] A. P. Gilakjani, and M. R. Ahmadi, "A Study of Factors Affecting EFL Learners' English Listening Comprehension and the Strategies for Improvement," Journal of Language Teaching and Research, September 2011. [Online]. Available: https://doi.org/10.4304/jltr.2.5.977-988. [Accessed February 12, 2021].

[10] Brown and Yule, Discourse analysis, Cambridge: Cambridge University Press, 1983.

[11] A. Nadig, Encyclopedia of autism spectrum disorders. Washington, DC: National Language Resource Centre, 2013.

[12] A. Prof, Ö. Kutlua, and A. Erman, "Factors affecting the listening skill," Procedia Social and Behavioral Sciences, vol. 1, no. 1, pp. 2013-2022, March 2009. [Online]. Available: https://doi.org/10.1016/j.sbspro.2009.01.354. [Accessed February 15, 2021].

[13] A. Gupta and P. Pathania, "To study the impact of Google Classroom as a platform of learning and collaboration at the teacher education level," Education and Information Technologies, vol. 26, pp. 843-857, August 2020. [Online]. Available: https://doi.org/10.1007/s10639-020-10294-1. [Accessed February 15, 2021].

[14] F. D. F. Davis, "Perceived usefulness, perceived ease of use, and user acceptance of information technology," MIS Quarterly, vol. 13, no. 3, pp. 319-340, September, 1989. [Online]. Available: https://doi.org/10.2307/249008. [Accessed January 16 2021]. 